\title{
Mia Couto: memória e «tradução cultural» em $O$ último voo do flamingo.
}

Mia Couto: memory and «cultural translation» in The Last Flight of the Flamingo.

\author{
José Paulo Cruz Pereira ${ }^{1}$
}

Resumo: A minha leitura segue o desafio com que somos confrontados, como uma espécie de enigma, no início do romance: «os soldados [da ONU] morreram? Foram mortos?» Em busca de uma resposta, pondera aquelas questões que dizem respeito aos problemas da morte e da vida, tal como eles são colocados no mundo ficcional de Tizangara. Compreendê-los-á, então, com base nas posições contidas em «Sobre uma crítica da violência», de Walter Benjamin e nos pensamentos, quer de Emma-nuel Lévinas, quer de Jacques Derrida. Eles ajudam-nos a compreender, do ponto de vista de uma crítica ética e política da violência, o que estará em causa, não apenas para a personagem do padre Muhando - a personagem que é o centro organizador da sua trama ficcional, e cuja visão nos parece fortemente marcado pelo judaísmo - mas também as do feiticeiro Zeca Andorinho e do velho Sulplício, que pertencem ao círculo das suas amizades mais próximas.

Palavras-Chaves: Justiça; memória; «vida nua»; alteridade.

\begin{abstract}
My reading follows the challenge the reader is confronted with, as a sort of enigma, at the beginning of the novel: «did the [UN] soldiers die? Were they killed?». Looking for an answer, it ponders those issues of life and death posed by the fictive world of Tizangara. Those concepts are understood by taking into account not only Walter Benjamin's positions, in his Critique of Violence, but also the thoughts of both Emmanuel Lévinas and Jacques Derrida. They are helpfull to grasp what is at stake, from the vantage point of an ethical and political critique of violence, not only for father Muhando - the character that is the organizing principle of the entire plot, and whose vision seems to be heavily influenced by judaism - but also for key-characters such as the wizard Zeca Andorinho and the old Sulplício being, both belonging to the circle of those that are closer to him.
\end{abstract}

Keywords: Justice; memory; «bare life»; alterity.

\footnotetext{
${ }^{1}$ Departamento de Artes e Humanidades da Faculdade de Ciências Humanas e Sociais da Universidade do Algarve.
} 


\section{Entre morrer e ser morto: «só os factos são sobrenaturais»...}

O último voo do flamingo é, provavelmente, o mais lido e celebrado dos romances do escritor moçambicano Mia Couto. Mas talvez o mais enigmático também. Com efeito, a sua abertura faz-se por um curioso preâmbulo. Referindo-se, por um lado, à história narrada e, por outro, quer às circunstâncias da sua escrita, quer aos efeitos da sua receção, aí se avança, no entanto, com um certo enigma. Como se formula ele?

Tudo começou com eles, os capacetes azuis. Explodiram. Sim, é o que aconteceu a esses soldados. Simplesmente começaram a explodir. Hoje, um. Amanhã mais outro. Até somarem, todos descontados, a quantia de cinco falecidos. Agora, pergunto: explodiram na inteira realidade? Di$z$-se, em falta de verbo. [...] Os soldados da paz morreram? Foram mortos? Deixo-vos na procura de uma resposta, ao longo destas páginas. (Couto, 2004: 11; sublinhado meu)

Eis, portanto, o desafio aí lançado ao leitor: «OS soldados da paz morreram? Foram mortos?». Qualquer busca de uma resposta nos obrigaria, aqui, à ponderação de um certo limite. Esse limite diria respeito, por um lado, à língua — os soldados teriam «explodido», não «na inteira realidade», mas «em falta de verbo»... Mas, por outro lado, ele prender-se-ia, também, com esta insinuada dificul- dade na distinção entre uma morte natural e outra cometida, ou exteriormente desencadeada. O quê / quem teria provocado essas explosões? Diversamente percorrido por cada das múltiplas leituras que tem suscitado, é possível verificar que todas elas convergem na constatação de que, como diria Phillip Rothwell, no seu Leituras de Mia Couto: aspectos de um pós-modernismo moçambicano: «O leitor nunca fica a saber o que aconteceu em Tizangara» (Rothwell, 2015: 178). Pois, como observaria também Ana Mafalda Leite, em «As personagens-narrativa em Mia Couto, um exemplo para começar: o personagem-tradutor de mundos», em $O$ último voo do flamingo:

O tradutor organiza a narrativa através dos testemunhos dos personagens da aldeia - o feiticeiro Andorinho, o padre Muhando, a puta Ana Deusqueira, o [adjunto do] administrador Chupanga, a velha-jovem amante Temporina - como uma narrativa percorrida por veios de muitas cores. Os motivos que levaram às explosões dos capacetes azuis efabulam-se a muitas vozes, que desorientam a escrita do relator das Nações Unidas, Massimo. (Leite, 2013: 170-171; sublinhado meu)

Ora, uma vez que Massimo Risi representa, também, a posição do leitor europeu que somos, o que se verifica é que:

Massimo vai de confusão em atordoamento, na impossibilidade de entender as falas narrativas, mesmo com tradutor. 
[...Pois] Tizangara, seus provérbios e ditos, seus personagens e «contadeirices» em estado permanente de mito, desorientam Massimo e o leitor, surpresos, de capítulo em capítulo. (Leite, 2013: 171)

Ou ainda, como nota, também, Carmen Lúcia Tindó Secco, no seu «Entre crimes, detectives e mistérios (Pepetela e Mia Couto - riso, melancolia e o desvendamento da história pela ficção)»:

Não é a língua que Massimo Risi não compreende, mas os modos de sentir, ver e pensar daquela gente. A hiância entre mundos diversos permanece, assim como também fica sem explicação a causa das explosões. Os depoimentos e falas das personagens representativas das tradições culturais moçambicanas, ao invés de esclarecerem o investigador, o confundem ainda mais. (Secco, 2011: 5; sublinhado meu)

Ora, é justamente a este propósito - o da «causa das explosões», ou o dos motivos que a elas conduzem... - que gostaríamos de situar a leitura a que aqui nos propomos. Acolhendo a presença dos soldados das Nações Unidas cujas estranhas mortes determinarão a necessidade do inquérito que justificará a presença do relator italiano Massimo Risi, incumbido de ali apurar as causas de tais misteriosos falecimentos -, Tizangara é, assim, o lugar de um mistério. Aberto - como seria de tradição - à presença, tanto dos seus antepassados já mortos, quanto dos seus deuses, a aldeia expõe-se, ainda, à ameaçadora presença de outras entidades - tanto vindas de dentro do país, quanto de fora dele, ambas pertencentes ao reino dos vivos. A vulnerabilidade de um tal espaço fica, aliás, bem patente no que nos diz Zeca Andorinho, no depoimento que presta a Massimo Risi:

É que aqui, na vila, ninguém nos garante. Nem a terra, que é propriedade exclusiva dos deuses, nem a terra é poupada das ganâncias. Nada é nosso nos dias de agora. Chega um desses estrangeiros, nacional ou de fora, e nos arranca tudo de vez. Até o chão nos arrancam. [...] Por exemplo: há dias esse administrador Jonas [...]. Agora, eu recebo ordem de um Jonas? Aqui, em Tizangara? Ele é estrangeiro, tal igual o senhor. (Couto, 1987: 156; sublinhados meus)

De resto, também no desabafo que tem com o filho - precisamente o narrador-«tradutor de Tizangara» - a personagem do velho Sulplício o exortará a que pense no que tais estrangeiros - uns de dentro: os «filhos estranhos» da pátria, aqueles que, pelo facto de a explorarem, dela fazem a sua «mina»... E outros de fora: os que, verdadeiramente, a minaram, fornecendo-lhe dispositivos para uma guerra com que podiam lucrar... - têm feito a Tizangara (e ao país):

- É que eu, assim, deixado e desleixado, me lembro a própria nossa terra. Porque a nossa pátria não via em si o apreço 
de seus filhos. [...] Fazia lembrar aquele homem que, de tanto ressuscitar, acabou morrendo. Eu que visse como haviam esburacado o nosso chão. Uns semeavam minas no país. Eram esses de fora. Outros, de dentro, colocavam o país numa mina. - Sabe, filho, o que é pior? I - E é o quê, pai? I - É que os nossos antepassados nos olham agora como filhos estranhos. (Couto, 1987: 210)

Sulplício compara-se, aqui, não apenas à sua própria terra, mas também a um Cristo. O mesmo Cristo que reaparecerá, aquando da prisão do padre Muhando - que «semelhava um Cristo negro, carregando uma invisível cruz» (Couto, 1987: 125). De resto, certos sinais se irão disseminando, ao longo do romance, que nos hão-de sugerir a possibilidade de antecipar a leitura que aqui trazemos, quanto à «causa da[quela]s explosões», que Carmen Lúcia Tindó Secco observa permanecerem por explicar. Para Sulplício - tal como para Zeca Andorinho, em boa verdade - o mal residia no facto de que «os novos-ricos se passeavam por um território de rapina, não tinham pátria. Sem amor pelos vivos, sem respeito pelos mortos» (Couto, 1987: 114). Como relacionar com este estado de coisas a explicação daquelas mortes que, implicando a desaparição dos soldados, terão, no entanto, lugar sem vestígios outros que não os de seus sobrantes adereços - uma bota, uma bóina... - e um órgão genital masculino: um pénis decepado? Mortes cuja estranheza permanece, neste sentido, por qualificar e atribuir: morreram? Foram mortos? Atentemos, uma vez mais, nas palavras do tradutor de Tizangara:

\begin{abstract}
Eles [os soldados da ONU], coitados, acreditavam ser donos de fronteiras, capazes de fabricar concórdias. [...] Agora pergunto: explodiram na inteira realidade? Diz-se, em falta de verbo. Porque de um explodido sempre resta alguma sobra de substância. No caso, nem resto, nem fatia. Em feito e desfeito, nunca restou nada de seu original formato. Os soldados da paz morreram? Foram mortos? Deixo-vos na procura da resposta, ao longo destas páginas. (Couto, 1987: 12; sublinhado meu)
\end{abstract}

Como compreendê-las, então, na economia ficcional e no universo efabulatório de $O$ último voo do flamingo? Não deveríamos nós procurar «a causa das explosões» igualmente por dentro das tradições da cultura ocidental, se o mundo de Tizangara fora, também, um espaço outrora colonizado?

\section{2. «Explodiram, na inteira realidade?»}

Uma comparação dos depoimentos reunidos por Massimo Risi e, mais tarde, transcritos por uma espécie de mallarmeana inspiração - para «português visível» (Couto, 2004: 11; cf. Blanchot, 1949: 39) pelo tradutor de Tizangara permitir-nos-á, contudo, observar aspectos que não vimos tratados por nenhum dos ensaios atrás mencionados. O que dos «soldados da paz» restava das explosões era, 
por um lado, o seu sexo decepado. Assim «nu e cru, eis o facto: apareceu um pénis decepado, em plena Estrada Nacional, à entrada de Tizangara. Era um sexo avulso e avultado» (Couto, 1987: 17; sublinhado meu), um «sexo maiusculino» (Couto, 1987: 34), como diria Ana Deusqueira, a prostituta de Tizangara. E é então que alguém sugere:

- Olhem lá no cimo da árvore! Era um desses bonés dos soldados das Nações Unidas. Pendurado num galho balançava na vontade das brisas. No instante que se confirmou a identidade da boina foi como navalha golpeando a murmuração. E logo-logo a multidão se irresponsabilizou. [...] E destroçaram, todos destrocados. Sobre o asfalto quente ficou o apêndice órfão. No ramo seco restou o chapéu missionário, plenamente só no meio das aragens. Azul em fundo de azul. (Couto, 1987: 18).

A pergunta é, pois, a seguinte: por que razão essa desaparição se haveria de marcar assim, no romance? O que poderia, portanto, ela significar — «azul em fundo azul» — para além de se constituir já como um obstáculo adicional à elaboração de qualquer relatório plausível? Com efeito, é precisamente por aí que o problema de «tradução» começa... No diálogo do ministro com o chefe da delegação da ONU:

- Não me venha com essa merda dos explodidos. Desculpe lá mas essa não engulo. [...] / - Escute bem: já desapareceram cinco soldados. Cinco! Eu tenho que dar relatório aos meus chefes em Nova lorque, não quero estórias nem lendas. / [...] E ouça: quero tudo gravado. Não quero bláblá, estou cansado de folclore. (Couto, 1987: 32-33)

Mas uma observação mais atenta constataria, por outro lado, o seguinte: que se tratava aí, de uma morte sem efusão de sangue... Vejamos alguns dos testemunhos. Por exemplo, o de Estêvão Jonas, na sua correspondência:

Já eu me deitava sobre ela, quando o clarão recintilou, parecia o cosmos se rasgava em dois. Me berlindaram os olhos. [...] Foi quando vi voar em minha direcção um órgão de macho, mais veloz que a fulminância de um relâmpago. [...] Depois de um tempo, aquele mesmo povo se acumulou junto ao galinheiro. Lá em cima estavam as botas do desditoso. E mais nenhum sinal: nem sangue nem vísceras, nem cheiro sequer. (Couto, 1987: 94-95; sublinhado meu)

Ou ainda o de Ana Deusqueira, que se deitara com um dos soldados mortos:

Fechei os olhos. Eu já tinha ouvido falar disso, dos estrangeiros explodirem quando montam nas meninas. Porém, nunca tinha acontecido comigo, nunca. Eu não queria nem abrir os olhos, ver a sangraria toda espalhada, tripas dependuradas nos candeeiros. Mas, afinal, não tive de limpar nada. O homem explodira que nem um balão. Aquele vivente se tinha espatifurado 
sem vestígio. (Couto, 1987: 185; sublinhado meu)

Ou ainda a versão do feiticeiro Zeca Andorinho:

Analise bem: o que é que resta dos explodidos? Uma perna? Um olho? Uma orelha? Só sobram as pichotas dos gajos. Sim, o resto se evapora. Já me foi visto homem sem pila. Mas agora, pila sem homem, me desculpe. O senhor me olha, ziguezagueando. [...] Então Ihe inquiro mais: por onde foi o sangue dos arrebentados? Por onde que nunca sobrou nem gota? (Couto, 1987: 158; sublinhado meu)

E, no entanto, em Tizangara, outras mortes tinham lugar. E essas implicavam derrama-mento de sangue. Como notaria a mesma Ana Deusqueira:

É que no meio de tudo há sangue, mortos a quem não cobriram o rosto. Esses mortos dormiram ao relento, impurificaram a noite. Para o senhor [Risi], com certeza, isso não traz gravidade. Aqui não é a morte, mas os mortos que importam. Ainda vai morrer mais gente, Ihe asseguro. Não faça essa cara. Espero que a desgraça lhe passe nas suas costas, a si que me parece um homem bom. (Couto, 1987: 181-182; sublinhado meu)

Tratar-se-ia, pois, de mortos a quem não tinham coberto o rosto: mortos cuja expressão nos interpelaria ainda - assombrando-nos. O mesmo constaria do testemunho de Sulplício que, ao som de uma das explosões, se pronunciaria assim:

- Esta é uma explosão das outras. / - Das outras? Que outras? / E me revelou, lacónico: era mentira que só explodissem soldados estrangeiros. Havia, segundo ele, outras explosões que matavam a nossa gente. Explosões verdadeiras, com prova de sangue e de lágrima. Como esta que tinha acabado de acontecer. / - Pai, me diga o que o senhor sabe... Com um gesto agitou negativamente o braço: nada, já tinha falado de mais. (Couto, 1987: 144)

Quem o confirmaria seria, de resto, Temporina. Essa morte com derramamento de sangue acabaria por atingir seu irmão:

- Mataram meu irmão. Seu único irmão, o moço tonto que herdara os bens de Hortênsia. A notícia era triste e colocava um novo elemento em toda aquela estória. O moço explodira. Desta vez, porém, era uma explosão real, dessas a que a guerra já nos havia habituado. (Couto, 1987: 147)

Que vida se esvaía, então, nessa sua morte?

O moço era lento e tonto, com tanto atraso na mente quanto no gesto. Nunca uma ideia visitara a sua cabeça e ele vivia tranquilo com a satisfação de um santo depois do pecado. O moço não era um fulano, nem um indivíduo. Assim, nem nome nenhum Ihe foi posto. Valia a pena desperdiçar um nome humano num ser 
de quem se duvidavam as propriedades?

(Couto, 1987: 66)

E como fora aquilo acontecer?

Tão simples quanto cruel: o moço pisara uma mina e as suas pernas se separaram do corpo como um esfarrapado boneco de trapos. Antes de chegar qualquer socorro se esvaíra em sangue. (Couto, 1987: 147)

O que poderia significar, então, essa diferença? Em «Sobre a Crítica do Poder como Violência», Walter Benjamin observa-nos, referindo-se às formas de comportamento com que, na sua experiência quotidiana, os homens lidam: «a cólera por exemplo, leva-os a evidentes explosões de violência, uma vez que não se relaciona, enquanto meio, com um fim proposto» (Benjamin, 2010: 65). E acrescenta Benjamin: «tais manifestações encontram-se, em primeiro lugar e de forma muito significativa, no mito» (Benjamin, 2010: 65). O exemplo que o atesta é a história mitológica de Níobe. Por ter depreciado Leto, ela acaba por ver os seus filhos mortos por Apolo e Artemisa (Graves, 1990: 227-228). Assim:

O poder mítico, na sua forma arquetípica, é mera manifestação dos deuses. Não meio para os seus fins, dificilmente manifestação da sua vontade, em primeiro lugar manifestação da sua existência. A lenda de Níobe contém um exemplo excelente desse poder. Poder-se-ia pensar que a acção de Apolo e Artemisa é apenas um castigo.
Mas o seu poder representa muito mais a institucionalização de um Direito novo do que a punição pela transgressão de um existente. (Benjamin, 2010: 65)

Porque não é, então, uma punição? Porque não se exerce na vigência de um direito pré-existente. De facto, se ela «institucionaliza um Direito novo» é porque a violência do poder «mítico» sobre Níobe «não é propriamente destruidora» (Benjamin, 2010: 65). Se o fosse tê-la-ia morto também. Se ganha força reguladora, é por passar a ser para efeitos da instituição de um Direito a respeitar que Níobe é poupada:

Apesar de provocar a morte sangrenta
dos [sete] filhos de Níobe, suspende-se
perante a vida da mãe, que deixa para
trás mais culpada que antes, carregando
eterna e mudamente essa culpa, um
marco que assinala a fronteira entre os
homens e os deuses (Benjamin, 2010: 65;
sublinhado meu)

A violência instituidora de direito é, portanto, não apenas fundadora de um direito, mas também, uma vez entendida a partir das suas origens míticas, sangrenta. Por isso não se deveria confundi-la com aquela outra a que Benjamin chama divina: «podemos confrontar com a lenda de Níobe [...] o juízo divino sobre o bando de Corah» (Benjamin, 2010: 67). Com efeito, na história bíblica da revolta de Corah e do «bando» que o acompanha, apresen- 
ta-se ele com «Datan e Abiram [...] com On». Comparecem eles com «duzentos e cinquenta filhos de Israel, príncipes da congregação e pessoas de posição» (Costa, 1978: 195) diante de Moisés e de Aarão, para contestar a sua liderança: «já basta da vossa parte! Toda a congregação é santa, todos são santos e no meio está o Senhor: porque então vos erigis em chefes de assembleia do Senhor?» (Costa, 1978: 195). Ora, para dar a reconhecer os eleitos de Deus, Moisés servir-se-á, então, da diferença entre a morte natural e a morte divina - não sangrenta - como critério:

Se esta gente morrer como todos os homens morrem; se o destino comum dos homens for também o deles, não foi o Senhor que me enviou; mas se o Senhor operar um fenómeno; se a terra abrir o seu seio para os engolir com tudo o que Ihes pertencer, e se eles descerem vivos ao sepulcro, então sabereis que estes homens ofenderam o Senhor. (Costa, 1978: 196)

E a punição divina, invocada por Moisés, logo se confirmaria:

Ora, logo que acabou de pronunciar estas palavras o solo que os sustentava fendeu-se. Abriu-se o seu seio e devorou-os, a eles e às suas casas, a todos os homens de Coré [isto é, de Corah ou de Korah] e a todos os seus bens. Desceram vivos ao sepulcro, eles e todos os seus: a terra fechou-se sobre eles e desapareceram do meio da congregação. (Costa, 1978: 196; sublinhado meu)

Que pensar desse «juízo» divino, que se abate sobre «o bando de Corah»?

\begin{abstract}
Esse juízo abate-se sobre os privilegiados, levitas. Atinge-os sem aviso prévio, sem ameaça, castigando e não hesitando em aniquilá-los. Mas ao mesmo tempo, ao aniquilar absolve da culpa, e não se pode negar uma profunda relação entre o carácter não sangrento e a absolvição patentes nesse poder. O sangue, de facto, é símbolo da vida nua. (Benjamin, 2010: 68; sublinhado meu)
\end{abstract}

Aproximamo-nos aqui de um indicador-chave... Se o sangue é o símbolo da vida nua, «o que é que distingue essencialmente a vida humana da dos animais e das plantas?» (Benjamin, 2010: 69). Para W. Benjamin, a vida nua, em si mesma considerada — da qual os seres humanos «vivos» participam... - não os esgota no seu ser, enquanto tal. Assim, se a repressão sangrenta, instituidora de Direito, se abate sobre os vivos - de que os filhos de Níobe são aqui um exemplo... - é porque ela não chega a distingui-los da vida nua de que eles participam sem, por isso, a ela exclusivamente pertencerem ou a ela se reduzirem. Quanto à violência divina - não sangrenta — que cai sobre «o bando de Corah», observará Walter Benjamin: 
Nesta medida será também legítimo designar este poder como aniquilador; mas é-o apenas de uma forma relativa, em relação a bens, ao Direito ou à vida, mas nunca absoluta, em relação à alma do ser vivo. [... Pois] É falso e vil o postulado de que a existência em si está acima de uma existência justa, se por existência não se entender mais do que a vida nua [...]. (Benjamin, 2010: 69; sublinhado meu)

Seria já, acrescenta Benjamin, o que se escutaria no mandamento bíblico: «Não matarás». A «o argumento de que, segundo a sua lógica, ela permitiria também, em determinadas condições, a violência letal dos homens uns contra os outros» (Benjamin, 2010: 68), ele responde que «o argumento não colhe, pois à pergunta "Posso matar?" segue-se, como mandamento, a resposta irrefutável: “Não matarás!”» (Benjamin, 2010: 68). Significaria isto que o mandamento condena toda e qualquer morte violenta? Não, pois, como Benjamin acrescenta: «Do mandamento não pode deduzir-se qualquer julgamento do acto. Por esta razão não se pode prever, nem o juízo divino do acto, nem a razão desse juízo» (Benjamin, 2010: 68). Daí a seguinte consequência:

E por isso não têm razão aqueles que pretendem fundamentar com o mandamento a condenação de toda e qualquer morte violenta de um ser humano por outro. Ele [o mandamento] não constitui medida de julgamento, é antes guia para a acção das pessoas ou comunidades que a ele recorrem na sua solidão e em casos inauditos assumem a responsabilidade da transgressão. (Benjamin, 2010: 68-69)

Observará Jacques Derrida, em Força de Lei, a este propósito:

O «não matarás» permanece um imperativo absoluto, a partir do momento em que o princípio da violência divina mais destrutiva ordena o respeito pelo vivente, para além do direito, para além do juízo. Porque este imperativo não é seguido por nenhum juízo. Não fornece nenhum critério para julgar. Não se podia apelar a ele a fim de condenar automaticamente toda a condenação à morte. (Derrida, 2003: 93; sublinhado meu)

Assim, se «a violência divina mais destrutiva ordena o respeito pelo vivente» (Derrida, 2003: 93) é necessário que este eleja, não «a vida por si mesma» - pois Walter Benjamin, lembra-o Derrida, «ergue-se com todo o vigor contra a sacralização da vida por si mesma» (Derrida, 2003: 93) - mas «a vida enquanto ela se prefere» (Derrida, 2003: 94). O que nesse princípio se consagra é, portanto:

[...] a vida para além da vida, a vida contra a vida, mas sempre na vida e para a vida. [...] O que faz o preço do homem, do $D a-$ sein e da sua vida, é conter a possibilidade da justiça, o porvir da justiça [... pois] o que é sagrado na sua vida não é a sua vida, mas a justiça da sua vida» (Derrida, 2003: 94; sublinhado meu). 
A vida para além da vida nua e contra ela: a «vida justa» ou que contenha a possibilidade da justiça. Enquanto violência justa, a «violência divina» seria, portanto, não apenas sem efusão de sangue, mas também em favor de uma «vida que se prefere» — vida que a si mesma se respeita e que, por esse respeito, se justificaria aos olhos de Deus. Tratar-se-ia, assim - na violência sangrenta e não-sangrenta - de duas violências de sinal contrário:

Dito de outro modo, a violência mitológica [grega, fundadora] do direito satisfaz-se em si mesma sacrificando o vivente, enquanto a violência divina sacrifica a vida para salvar o vivente, a favor do vivente. Em ambos os casos há sacrifício, mas no caso em que o sangue é exigido, o vivente não é respeitado. (Derrida, 2003: 92-93; sublinhado meu)

E é precisamente «aí [que] reside, para Benjamin, a essência do judaísmo, que recusaria expressamente condenar o assassínio em caso de legítima defesa» (Derrida, 2003: 93; sublinhado meu). Como é que estas posições nos poderiam ajudar na compreensão daquilo de que se trata, em $O$ último voo do flamingo?

\section{A igreja do padre Muhando junto}

\section{ao rio: as pegadas de Deus...}

Para se entenderem as implicações desta aproximação, seria preciso começar por escutar, com alguma atenção, a versão do padre Muhando... Não nos limitarmos a assinalar a descoberta da autoria do crime da reimplan- tação das minas - como acontece com vários dos seus comentadores (cf. Rothwell, 2015: 182; Brugioni, 2012: 88): a de Ana Deusqueira. Mas escutar aquilo de que o padre «já suspeitava» - é o seu testemunho - e que só o descrédito em que caíra, por causa da bebida, Ihe não permitira denunciar. O padre Muhando, a cujo círculo de amigos pertenciam - ver-se-á a importância disto - Zeca Andorinho e Suplício, e cuja compreensão do que está em jogo, em Tizangara, parece transcender, em muito, a descoberta de Ana Deusqueira. Que nos diz então Muhando?

\begin{abstract}
Passava-se, afinal, o seguinte: parte das minas que se retiravam regressava, depois, ao mesmo chão. Em Tizangara tudo se misturava: a guerra dos negócios e os negócios da guerra. No final da guerra restavam minas, sim. Umas tantas. Todavia, não era coisa que fizesse prolongar tanto os projectos de desminagem. O dinheiro desviado desses projectos era uma fonte de receita que os senhores locais não podiam dispensar. (Couto, 2004: 200)
\end{abstract}

Nesse «negócio da guerra», por conseguinte, «umas mortes à mistura até calhavam, para dar mais crédito ao plano» (Couto, 2004: 200). Mas isso surtiria efeito enquanto se tratasse das mortes de «gente anónima, no interior de uma nação africana que mal sustenta seu nome no mundo. Quem se ocuparia disso?» (Couto, 2004: 200) O problema é que esse projecto não contara com a vinda dos capacetes azuis: 
- Mas depois veio esse desacontecimento! I

- Qual desacontecimento, padre? A morte dos capacetes azuis. Terem explodido estrangeiros foi o que desmontou o esquema. O feitiço dos estrondeados prejudicou a trapaça. Se atraíram atenções indevidas. A verdade das minas pedia provas de sangue. Mas sangue nacional. Nada de hemorragias transfronteiriças. (Couto, 2004: 200)

O administrador da vila de Tizangara - Estêvão Jonas - chamaria, então, o feiticeiro Zeca Andorinho: «deu ordem para que aquilo terminasse, de imediato. Mais nenhum soldado da ONU poderia desaparecer» (Couto, 2004: 200):

- E Zeca Andorinho o que respondeu? I Zeca mentiu, disse que aquilo era feitiço de fora. Que eram fenómenos extralocais, comandados por forças maiores. E disse ele não tinha mão naquelas sobre naturezas (Couto, 2004: 200-201).

Porque diria, no entanto, o padre Muhando, que Andorinho mentiu? Que teria significado dizer que esse feitiço era de dentro? Em que medida, em Tizangara, fora e dentro se distinguiam? Uma resposta começará a esboçar-se à chegada de Temporina. Conta ela que o adjunto Chupanga conduzia já, por essa altura, o administrador a caminho da fronteira - ao encontro de Jonassane, o primo cúmplice dos desvios de fundos. Regressado, o adjunto cumpriria, então, a missão que Ihe fora atri- buída: fazer rebentar a barragem do rio Madzima e, inundando tudo, destruir as provas do crime. Sulplício diz então ao filho:

- Vá meu filho, se apresse a evitar essa tragédia. Vá à barragem, antes que esse satanhoco lá chegue. [...] Leve esta pistola, mate-me esse Chupanga. / Eu não tinha ouvidos para tais palavras. Matar? Sim, matar essa minhoca que não era gente. Neguei-me, sem sangue, sem voz. I - Você não tenha coração que aquilo não é homem. Simples bicho. (Couto, 2004: 201-202)

Diante da inicialmente silenciosa recusa de seu filho - que a isso se nega, «sem sangue, sem voz», note-se... - Sulplício insiste. Mesmo quando o filho lembra ser, seu pai, também ele pouco afeito às incumbências de qualquer execução sumária:

- Mas o senhor, pai, não se lembra? O senhor nem o flamingo matou quando Ihe foi mandado. I - Já disse, dispare nos miolos desse demónio. Até aqui o padre Muhando o abençoa. Não é padre? (Couto, 2004: 202)

Porque havia o padre Muhando de o abençoar? Uma correspondência com o pensamento judaico-cristão de Walter Benjamin parece-nos começar a esboçar-se. E ela estender-se-á mesmo às palavras que, de Zeca Andorinho, então, se seguem:

Zeca Andorinho tomou posse: me sacou a pistola da mão e a enfiou no cinto. E disse: 
- Eu mesmo farei justiça - apontando o revólver, acrescentou: - Este será o meu melhor feitiço! (Couto, 2004: 202-203) póstumos, para cima do canhoeiro. E aterraram na estrada nacional, às vistas de todos. (Couto, 2004: 125-127)
Em que sentido justiça e feitiço se aliariam aqui? Pois que é, então, de uma «vida justa» uma «vida que a si mesma se prefere» - que se trata... Haveria, no entanto, alguma relação de partilha de tais pressupostos, entre o padre e o feiticeiro? Aquando da sua prisão, o padre Muhando «Vinha descalço, sem camisa. SemeIhava um Cristo negro, carregando uma invisível cruz» (Couto, 2004: 125)... E o seu testemunho começa por ser um tanto surpreendente:

- Que se passa? I - Prenderam um homem. / Fomo-nos aproximando dos polícias que escoltavam um homem pequeno, coxo. Estava de costas, mas, quando se virou, vi que era o padre Muhando. [...] - Padre Muhando! / - Dizem que fui eu que fiz as explosões. / - Que disparate! E o padre não Ihe explicou? / - Expliquei, confessei tudo. /Confessou? I - Sim. Fui eu mesmo que fiz explodir essa estrangeirada. (Couto, 2004: 125)

Risi e o tradutor visitam-no, no dia seguinte, na tentativa de melhor compreenderem o que se tinha passado:

A seguir o sacerdote pareceu disposto a prestar informação. Mas ele só fingia. Porque explicou: o soldado explodido era um homem feio. Tinha os tomates maiores que os do boi-cavalo. Até a andar se ouviam os badalões dele. Dizia isto, não porque os tivesse visto em vida. Os ditos voaram,
«Fingiria» de facto? Diante desse achado, com quem se encontraria ele? Precisamente com Zeca Andorinho: «o nyanga [o feiticeiro], que ele chamava de "colega"»(Couto, 2004: 127). E para quê? «Para dar destino às partes do [soldado] zambiano» (Couto, 2004). Porque:

Já voavam abutres de rapina sobre a copa da grande árvore. Seria chamar desgraça se se deixassem aquilos assim, à disposição dos bichos. Nunca mais haveria sossego, caso os pássaros engolissem os mbolos do estrangeiro. A bicheza não visita lugar da gente. Pelo menos, sem o devido assentimento. E o padre: - Como o senhor, que nos visita sem nos perguntar - disse, apontando o italiano. (Couto, 2004: 127)

O italiano fazia, portanto, parte daquela mesma bicheza, da impureza dessa vida pura e simples: de uma «vida nua», em suma... Era, pois, junto dela que ele devia estar. «O que fizeram então ele e o feiticeiro?» (Couto, 2004: 127). Juntos: 
de descrédito. Confirmava o que tinha ouvido dizer: o religioso enlouquecera, esquecendo as suas obrigações. (Couto, 2004: 127)

Porque se dizia, no entanto, que ele «enlouquecera, esquecendo-se das suas obrigações»? As razões hão de reconduzir-nos ao problema inicial do tradutor: «Explodiram na inteira realidade?»... Pois como situar, então, uma morte que se diria, por um lado, natural - pois eles morreram em consequência da sua cupidez, do ciúme despertado nos homens pela sua presença, junto das mulheres da aldeia... Zeca Andorinho dirá mesmo, no seu depoimento:

Quer saber como ficaram capados? Ora, Excelentíssimo: cada um deixa cair o que não pode segurar. Eu, Zeca Andorinho, seguro bem as minhas dependências. Não ando por aí a meter a moca no trombone. O senhor sabe: tudo cai, até nuvem tomba do céu. Quem sofre as culpas disso? Ninguém. Estou a sério, doutor. Não sei o que aconteceu - com todo o respeito da ignorância. [...] Os anjos é que são testemunhas miloculares. O melhor é entrevistar-Ihes. (Couto, 2004: 155)

E, por outro lado, resultante de uma punição divina - foram mortos, sem que alguém premeditadamente os matasse, por terem pisado as minas que tinham provocado já outras mortes, menos transfronteiriças e internacionais: uma morte sem vísceras nem sangue. Porque se dizia, então, que o padre «enlouquecera»?

Várias vezes se ouvira o sacerdote insultando Deus pelas ruas públicas. Morria uma criança, indefesa contra o sofrimento, e Muhando saía da igreja e desafiava o Criador, ofendendo-o em frente de todos. Chamava-lhe os piores nomes. / É verdade que ofende Deus? I Q Qual Deus? I - Bom... Deus. / Ah, esse. É verdade, sim. Eu insulto-O quando ele se descom-porta. (Couto, 2004: 128)

A sua equacionação pagã - entre «esse Deus» e os restantes, talvez mais antigos, como veremos... - lembra-nos aqui o Ricardo Reis de «Não a ti, Cristo, odeio ou menosprezo»:

Não a ti, Cristo, odeio ou menosprezo / Que aos outros deuses que te precederam / Na memória dos homens. / Nem mais nem menos és, mas outro deus. // No Panteão faltavas. Pois que vieste / No panteão o teu lugar ocupa, / Mas cuida não procures / Usurpar o que aos outros é devido. (Reis, 1987: 74)

Ora, a esse Deus - nem mais nem menos do que os outros que o precederam - por que O insultava o padre Muhando? É que, conforme explicava:

Tinha razões para essa intimidade - ele e Deus eram colegas, sabedores de segredos mútuos. Quando ele bebia, Ele bebia também. Por isso ele não rezava a 
Deus. Antes rezava com Deus (Couto, 2004:

128; sublinhado meu).

Essa proximidade o daria já como corresponsável por aquelas mortes: «Sim. Fui eu mesmo que fiz explodir essa estrangeirada» (Couto, 2004: 125). O mesmo seria dizer que tinha sido Ele - o mesmo Deus com quem ele rezava... - quem punira aquela «estrangeirada». E o seu discurso articula-se, então, com um irrepreensível rigor:

Falou tudo de enfiada rosariando as palavras como quem estivesse no esgotar do tempo. - O senhor me olha, pensa que eu sou um doido lunático. Mas tanto faz-me. I - Por amor de Deus, eu não penso nada - ripostou Massimo. - Agora, uma coisa: o senhor nunca, mas nunca me fotografe! Nem me grave. Quem é o senhor para andar a gravar e fotografar sem autorização? (Couto, 2004: 126)

Em que sentido? Diz-nos Emmanuel Lévinas, em «Interdit de la représentation où les droits de l'homme», um dos textos de Altérité et transcendance:

«Interdit de la représentation» - relatif d'ailleurs, dans la tradition juive, à certaines images seulement [...] on ne devrait pas laisser à la légère circuler cette formule [...] sans examiner, au préalable, de très près, ce que disent la Loi écrite de la Bible et, dans son langage à plusieures dimensions et niveaux, la Loi orale du Talmud où, d'ailleurs, quand il s'agit d'une recherche scientifique, toute représentation est authorisée. (Lévinas, 1995: 127-128)

E porquê? Porque, tal como no caso do padre Muhando - que reza com Deus e com ele vive... - o que nessa interdição da idolatria se marca é, precisamente, uma proibição da redução da transcendência que seria o equivalente à aniquilação perpetrada pela «paixão do assassínio». Assim, o que pela sua representação - fotografia ou gravação, diante de Risi... - se atingiria seria, então, a própria:

Unicité de l'unique dans son genre - ou unicité ayant rompu tout genre - au sens où l'aimé est unique pour l'aimant. Unicité qui, à l'aimant, d'emblée, signifie la crainte pour la mort de l'aimé. Or, dans l'image, la pensée accède au visage d'autrui réduit à ses formes plastiques, fussent-elles exaltées et fascinantes et procédant d'une imagination exacerbée. Fussent-elles oeuvre d'art! (Lévinas, 1995: 128-129)

Único, na sua proximidade e, nisso, tão (co-) responsável como irrepresentável...

Dans l'interdit de la représentation» on ne met pas seulement en question le privilège exclusif que la culture occidentale aurait conféré à la conscience et à la science qu'elle porte en elle et qui, conscience de soi, se promettrait ultime sagesse et pensée absolue. (Lévinas, 1995: 131) 
Do que se tratara fora sempre daquela abusiva redução do outro que foi merecendo na frente anticolonial do combate pela liberdade, ou no esforço pela autodeterminação, enquanto exercício do direito de separação (e sabe-se o quanto esta palavra vale, no léxico de Lévinas)... - a mesma contestação que lhe deveria merecer todo o ódio ou o desejo de matar:

Question qui ne se soulève certainement pas parce que la représentation ne serait vouée qu'à la matérialité de la chose, comme si elle était incapable de d'abstractions et ne pouvait pas viser le non-matériel. Mais parce que, dans la présence qu'elle ne cesse pas de renouveler, s'accomplit toujours l'adéquation de la pensée à son autre; parce que, intentionnalité, elle vise toujours «quelque chose»: un but, une fin, un fini, un terme. (Lévinas, 1995: 131; sublinhado meu)

Ora, não é Deus infinito? Procurar reduzi-l'O às suas (inencontráveis) feições plásticas... Não seria isso já conforme a uma certa «paixão do assassínio»? (Lévinas, 2008: 229-230)

\section{Sulplício e «o bando de Corah»: um céu debaixo da terra...}

Mas não eram só o padre Muhando e Zeca Andorinho que entravam no círculo dessa proximidade. Também Sulplício, que replicaria, ao adjunto Chupanga, quando este lhe manifesta a intenção de lhe vir a oferecer, um dia, um cargo político:
- Até já tinha pensado em Ihe oferecer a responsabilidade aqui da seç̧ão de Tizangara. Você tem a aceitação das massas. [...] / Você não entende, eu só aceitaria se ficasse a dirigir mais alto. I-A nível de província? / - Mais alto. / - Da nação? / - Mais alto, muito mais alto. (Couto, 2004: 208)

Em que sentido iria, então, essa sua ambicionada altura?

\begin{abstract}
Os outros acreditavam ser mania de grandeza. Contudo meu pai, só eu sabia, referia-se a outras dimensões, a outra altura. Essa inatingível, onde nem homens nem suas infelicidades se distinguem. (Couto, 2004; sublinhado meu)
\end{abstract}

Não espantaria, pois, ouvir Sulplício responder - depois de lhe haver prometido «mostrar o que aconteceu com os soldados explodidos» (Couto, 2004: 210):

- Então, senhor Sulplício: vai ou não vai me explicar a razão dos desaparecimentos dos meus homens? / - Não sou eu que irei falar. Quem vai falar é este lugar. I - O lugar? I - Sim, este mesmo lugar. É por isso que viemos aqui, senão eu já tinha falado lá na vila. (Couto, 2004: 218)

Que tinha pois esse lugar? «Meu pai explicou: ele só podia falar no lugar que lhe era sagrado, junto ao rio Madzima. [...] - Sigo o padre Muhando: neste lugar também eu converso com Deus» (Couto, 2004: 218; sublinhado meu). 
Onde ficava esse lugar? Justamente ali, onde o padre Muhando tinha a sua «igreja»:

- Sabe onde é a minha verdadeira igreja? Sabe? É junto ao rio, lá no meio dos caniços. Subiu a um caixote e espreitou da janela [da prisão]. [...] - Veja. É ali que converso com Deus. I - Porquê ali? I - Porque é ali que estão as pegadas de Deus. [...] - Ali naqueles caniços: aquela é a minha igreja. Lá eu me debruço para olhar os olhos de Deus. Falo com ele através da água. (Couto, 2004: 128-129)

Que «explicação» advirá, então, desse lugar? Eis o que o tradutor nos diz:

Foi num súbito: acordei em sobressalto. É que no meu rosto senti o bafo das infernezas. Olhei para o lado e quase desfaleci: ali mesmo, onde estava a terra, não havia nada senão um imenso abismo. Já não havia paisagem, nem sequer chão. Estávamos nas margens de um infinito buraco. (Couto, 2004: 219; sublinhado meu)

Que acontecera então?

Como a inteira paisagem, a casa, a vila, a estrada. Tudo engolido pelo vácuo. Um homem faz um grande buraco, sim. Muitos homens fazem um buraco muito enorme. Uma cova daquela dimensão, porém, aquilo era obra da sobrenatureza. Chamámos o italiano que se inacre-ditou: o país inteiro desaparecera? Sim, a nação fora toda engolida nesse vácuo. (Couto, 2004: 219; sublinhado meu)
Razão haveria tido o «tradutor» para, logo no início do romance, nos confidenciar: «em Tizangara, só os factos eram sobrenaturais. E contra factos tudo eram argumentos» (Couto, 2004: 17). Como com «o bando de Corah», tudo e todos teriam então resvalado chão abaixo. Sumido por esse céu que haveria debaixo da terra - sepulcro abaixo... - por essa imensa pegada de Deus. Na versão de Sulplício:

Já acontecera com outras terras de África. Entregara-se o destino dessas nações a ambiciosos que governavam como hienas, pensando apenas em engordar rápido. [...]. Vendo que solução não havia, os deuses decidiram transportar aqueles países para esses céus que ficam no fundo da terra. [...] Nesse lugar onde nunca nada fizera sombra, cada país ficaria em suspenso, à espera de um tempo favorável para regressar ao próprio chão. (Couto, 2004: 220-221; sublinhado meu)

E nesse limbo permaneceriam ainda, pois: Até lá era o vazio do nada, um soluço do tempo. Até lá gente, bichos, plantas, rios e montes permaneceriam engolidos pelas funduras. Se converteriam não em espíritos, pois essas são criaturas que ocorrem depois da morte. E aqueles não haviam morrido. Transmutaram-se em não-seres, sombras à espera das respectivas pessoas (Couto, 2004: 220-221; sublinhados meus). 
Como dizer, então, que os soldados morreram sem morrer naturalmente, embora tivessem sido mortos sem assassinato, por uma «punição» divina que os castrasse, deixasse em suspenso, fulminasse? Com razão protesta seu filho, na nota preambular do romance: «o que se passou só pode ser contado por palavras que ainda não nasceram. (Couto, 2004: 11; sublinhado meu). Intuição que o colocaria na mesma posição que Zeca Andorinho - o «nyanga» a quem o padre Muhando trata por «colega». No seu depoimento a Risi, Zeca dirá:

Me escute, senhor: estou vivendo apenas em rascunho, amanhando uns biscatos de futuro. É que aqui, na vila, ninguém nos garante. [...] Agora o senhor me pergunta por esses soldados que desapareceram-se. Pergunta-me se o soldado zambiano morreu. Morreu? Bem, morreu relativamente. Como? O senhor me pergunta - como se morre relativamente. Não sei, não the posso explicar. Teria de falar na minha língua. (Couto, 2004: 156-157; sublinhados meus).

Falando em português, Andorinho não falava pois - já e ainda... - na sua língua. Se a sua condição era a daqueles a quem, na vila, nada se garante - «Até o chão nos arrancam» (Couto, 2004: 156) - tal acontecia, igualmente, na experiência do desencontro das línguas em que se exprime. No chão dessas línguas - que assim lhe foge como se uma enorme fenda nele se abrisse... - se joga, então, o seu futuro, a sua sobrevivência: «Digo isto por vistoria: não confianço em ninguém, estamos a ser empurrados para onde não há lugar nem data certa» (Couto, 2004: 156; sublinhado meu). Precisando de reformular o português a partir da sua língua materna ele está «vivendo em estado de rascunho»... Daí esse conceito de morte relativa ser

\begin{abstract}
[...] coisa que nem este moço não pode traduzir. Para o que havia que falar não há palavras em nenhuma língua. Só tenho fala para o que invento. [...] Está a ver minha educação? Falam muito de colonialismo. [...] O que fizeram esses brancos foi ocuparem-nos. Não foi só a terra: ocuparam-nos a nós, acamparam no meio das nossas cabeças. Somos madeira que apanhou chuva. Agora não acendemos nem damos sombra. Temos de secar à luz de um sol que ainda não há. (Couto, 2004: 158)
\end{abstract}

Assim, para que se entenda aí a modulação de sentido trazida pelo advérbio - nesse «morrer relativamente»... - é preciso fazer intervir a noção de um fim que a sua cultura não reconhece. Pois, como ele dirá, a certa altura, a Massimo Risi:

Os seus chefes estão lá fora, não é? Pois os meus estão ainda mais fora. Está compreender? Viver é fácil: até os mortos conseguem. Mas a vida é um peso que precisa ser carregado por todos os viventes. A vida, caro senhor, a vida é um beijo doce em boca amarga. Entende, o senhor? (Couto, 2004: 157; sublinhado meu) 
Porque:

O tempo aqui é de sobrevivências. Não é como lá, na sua terra. Aqui só chega ao futuro quem vive devagarzito. Nos cansamos só a afastar os maus espíritos. (Couto, 2004: 157; sublinhado meu)

«Explodidos», os soldados se teriam resumido, por sinédoque, ao sexo «avulso e avultado» em que, deles sobrando, eles se resumiam afinal: esse seu «hífen carnal» (Couto, 2004: 31): pois «eles coitados, acreditavam ser donos de fronteiras, capazes de fabricar concórdias» (Couto, 2004: 12). Esse «hífen carnal» sobre o qual «o representante do governo central [...] meta-fisicou hipótese: aquilo, em plena estrada, era um órgão ou um organismo?» (Couto, 2004: 28; sublinhado meu)... Talvez um organismo $-\operatorname{sim} . .$. mas a contraexemplo de "uma vida que se prefere»: um exemplo de vida nua... Porque, como diria Lévinas, em «Paix et proximité»:

Cette histoire d'une paix, d'une liberté et d'un bien-être promis à partir d'une lumière qu'un savoir universel projetait sur le monde et sur la société humaine [...] cette histoire ne se reconnaît pas dans ses millénaires de luttes fratricides, politiques et sanglantes, d'impérialisme, de mépris humain et d'exploitation, jusque dans notre siècle de guerres mondiales, des génocides, de l'holocauste, et du terrorrisme; du chômage et de la misère continue du Tiers monde. (Lévinas, 1995: 137)

\section{Bibliografia}

Bhabha, H. (1994). The Location of Culture. Routledge. New York;

Benjamin, W. (2010). O anjo da História. Assírio \& Alvim. Lisboa;

Blanchot, M. (1949). La part du feu. Galimard. Paris;

Brugioni, H. (2012). Representação, história(s) e pós-colonialidade. Húmus. Braga;

Costa, A., et al. (1978). Bíblia sagrada. Difusora Bíblica. Lisboa;

Couto, M. (2004). O último voo do flamingo. Caminho. Lisboa;

Derrida, J. (2003). Força de lei. Campo das Letras. Porto;

Graves, R. (1990). Os mitos gregos - I. Dom Quixote. Lisboa;

Leite, A.M. (2013). Ensaios sobre literaturas africanas. Alcance Editores. Maputo;

Lévinas, E. (1995) Altérité et transcendance. Fata Morgana. Paris;

Lévinas, E. (2008). Totalidade e infinito. Edições 70. Lisboa;

Reis, R. (1987). Odes. Ática. Lisboa;

Rothwell, P. (2015). Leituras de Mia Couto. Almedina. Lisboa;

Secco, C.L.T. (2011). Entre crimes, detectives e mistérios (Pepetela e Mia Couto - riso, melancolia e o desvendamento da história pela ficção)». Mulemba, 5. Acedido em: https:// revistas.ufrj.br/index.php/mulemba/issue/ view/426/showToc 